\title{
PELATIHAN PEMBUATAN WEBSITE SEKOLAH MENGGUNAKAN WORDPRESS UNTUK GURU TIK SMA NEGERI 17 PALEMBANG
}

\author{
Siska Devella1), Yohannes ${ }^{1}$, Nur Rachmat ${ }^{1)}$ \\ 1)Teknik Informatika, STMIK Global Informatika MDP, Palembang, Sumatera Selatan, Indonesia \\ Corresponding author : Siska Devella \\ E-mail : siskadevella@mdp.ac.id
}

Diterima 10 April 2021, Direvisi 15 April 2021, Disetujui 16 April 2021

\begin{abstract}
ABSTRAK
Kegiatan pengabdian kepada masyarakat dalam bentuk pelatihan pembuatan website sekolah dengan menggunakan WordPress bertujuan untuk meningkatkan kompetensi dan pemahaman serta mengasah keterampilan Guru TIK di SMA Negeri 17 Palembang dalam membuat dan mengelola website. Terdapat tiga tahapan utama yang dilakukan dalam pengabdian ini antara lain tahap perencanaan yang dibagi menjadi studi lapangan, analisis kebutuhan serta perizinan, tahap kedua yaitu pelaksanaan kemudian dilanjutkan dengan tahap evaluasi. Hasil evalusi terhadap kegiatan pengabdian yang telah dilakukan adalah pelatihan pembuatan website sekolah tersebut mampu meningkatkan pengetahuan dan keterampilan guru TIK di SMA Negeri 17 Palembang dalam menghasilkan tampilan website sekolah yang lebih menarik dan interaktif.
\end{abstract}

Kata kunci: pengabdian kepada masyarakat; guru TIK; website; wordpress

\begin{abstract}
Community service activities in the form of training on creating school websites using WordPress aim to improve competence and understanding as well as hone the skills of ICT Teachers at SMA Negeri 17 Palembang in creating and managing websites. There are three main stages carried out in this service, including the planning stage which is divided into field studies, needs analysis, and licensing, the second stage is implementation then followed by the evaluation stage. The result of the evaluation of the community service activities that have been carried out is that the school website creation training can increase the knowledge and skills of ICT teachers at SMA Negeri 17 Palembang and can produce a more attractive and interactive appearance of the school website.
\end{abstract}

Keywords: community service activities; ict teachers; website; wordpress

\section{PENDAHULUAN}

Perkembangan teknologi informasi dan komunikasi saat ini secara tidak sadar telah mengubah proses kerja menjadi digital. Hal ini membuat berbagai aktivitas mengalami perubahan dalam mencari informasi. Saat ini informasi sangat mudah dicari melalui akses website melalui internet. Pentingnya website bagi sekolah membuat informasi terbaru terkait 406 endidikan dapat dikenal lebih luas oleh pengguna internet.

Melalui website, sekolah dapat memberikan informasi terkait kegiatan sekolah sehingga lebih tepat guna dan informatif. Website sekolah bukanlah hal yang baru, namun tata cara pengelolaan dan kemudahan dalam mengelola serta beberapa fitur keamanan yang mudah diimplementasi oleh orang banyak merupakan hal yang dapat mendukung proses pengembangan website yang dapat dilakukan secara optimal. Dengan mobilitas yang tinggi, sekolah dapat mengoptimalkan website-nya sehingga nantinya dapat menjadi sarana penunjang pendidikan sesusai dengan kemajuan teknologi. Pada masa pandemi Covid-19 ini, website sekolah kini tengah menjadi sarana yang dapat digunakan di dunia pendidikan dan dapat menjadi media pembelajaran online. Website sekolah juga dapat menjadi media promosi untuk berbagai pihak baik dari bidang kependidikan, kesiswaan, hingga masyarakat luas. Salah satu software yang dapat digunakan dalam pengelolaan website sekolah adalah Content Management System.

Content Management System (CMS) adalah sebuah software (perangkat lunak) yang banyak digunakan untuk melakukan pengelolaan website seperti menambah, mengubah, dan menghapus konten dalam suatu website (Siambaton \& Fakhriza, 2016). Secara umum, CMS terdiri dari dua bagian utama, yaitu front-end dan back-end. Bagian front-end merupakan halaman web yang 
diakses oleh pengunjung web dan bagian backend merupakan halaman web yang diakses oleh pihak pengelola website itu sendiri. Salah satu CMS yang dapat memenuhi kebutuhan ini adalah WordPress.

WordPress merupakan sebuah CMS yang dapat digunakan untuk mengelola konten halaman web (Pratiwi et al., 2020). WordPress dapat menjadi alternatif dalam membuat halaman web yang lebih mudah tanpa harus menguasai bahasa pemrograman. WordPress memiliki pengaturan yang dapat disesuaikan dengan kebutuhan halaman web yang diinginkan.

WordPress dapat digunakan untuk membuat halaman web seperti blog, situs $e$ commerce, portofolio, newspaper atau pun jenis yang lainnya. Salah satu keunggulan WordPress adalah mudahnya proses instalasi dan pembaruan serta kustomisasi halaman web. WordPress juga memiliki banyak variasi plugin yang dapat digunakan untuk mendukung pengembangan web.

Salah satu plugin WordPress yang digunakan dalam pengembangan website sekolah SMA Negeri 17 Palembang adalah Elementor. Elementor merupakan salah satu page builder yang digunakan untuk membuat halaman web menjadi lebih menarik meliputi landing pages, opt-in forms, widget, pop-up, dan sebagainya (Pamungkas et al., 2020).

Plugin All In One WP Security juga digunakan sebagai plugin untuk keamanan tambahan pada website sekolah SMA Negeri 17 Palembang. Plugin ini dapat menambahkan keamanan pada halaman website meliputi keamanan akun, login, pendaftaran pengguna, database, dan pencegahan serangan masuk ke halaman website sekolah (Petreski et al., n.d.).

Untuk meningkatkan jumlah trafik pada website sekolah dapat juga digunakan Google analytics. Google analytics juga dapat diterapkan di WordPress. Google analytics merupakan layanan gratis dari Google yang dapat menampilkan informasi terkait trafik website dan perilaku pengunjung website. Google analytics mampu memberikan informasi lengkap tentang pengunjung, mengoptimalkan strategi pemasaran, mempertahankan kualitas konten, dan mengidentifikasi waktu yang paling efektif (Hendriadi \& Dedih, 2015).

SMA Negeri 17 Palembang telah memiliki website sekolah namun tampilan pada halaman web belum responsif. Tidak hanya itu, pihak pengelola website sekolah juga kesulitan untuk melakukan kustomisasi pada halaman web. Website sekolah sebelumnya juga tidak user-friendly untuk pengguna.

Tujuan dari kegiatan ini diantaranya memberikan wawasan kepada guru TIK SMA
Negeri 17 Palembang dalam menggunakan WordPress untuk membuat dan mengelola website sekolah. Guru TIK dapat menambahkan konten layaknya pengelola dalam memposting informasi melalui halaman web terkait pengumuman, materi, dan prestasi sekolah.

\section{METODE}

Metode Pelaksanaan Pengabdian Kepada Masyarakat yang telah dilakukan pada tanggal 04 Maret 2021 di SMA Negeri 17 Palembang adalah berupa kegiatan pelatihan yaitu dengan memberikan materi mengenai pembuatan website sekolah menggunakan WordPress, dimana peserta pelatihan yaitu Guru mata pelajaran TIK (Teknologi Informasi dan Komunikasi) di lingkungan SMA Negeri 17 Palembang. Kegiatan pengabdian ini dilakukan dalam tiga tahap, antara lain yaitu tahap perencanaan, tahap implementasi dan tahap evaluasi, dapat dilihat pada Gambar 1.

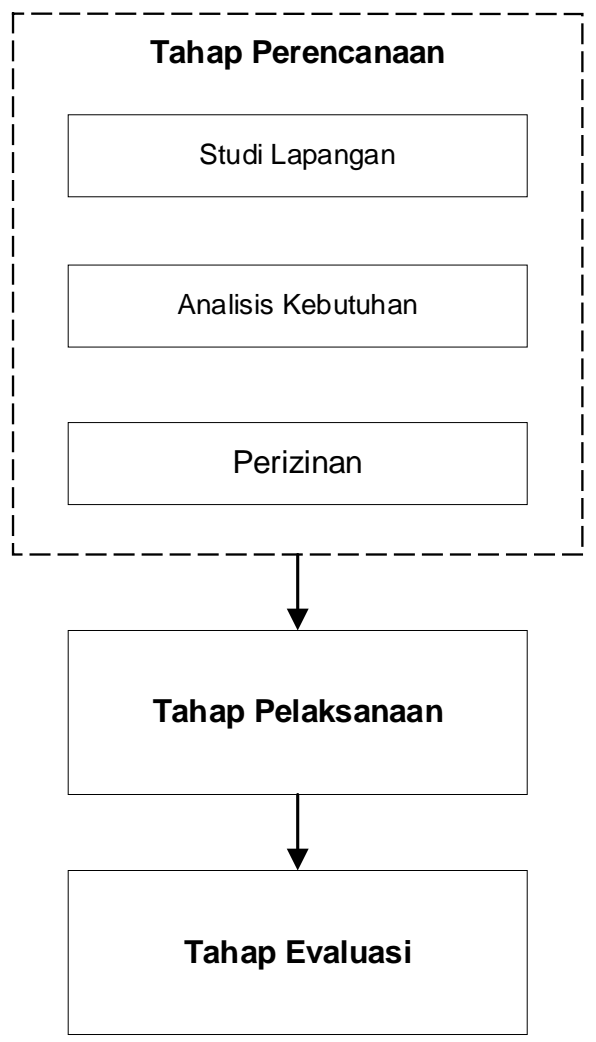

Gambar 1. Tahapan Kegiatan Pengabdian Kepada Masyarakat

Berikut ini adalah tahapan pelatihan pada kegiatan pengabdian yang dilakukan :

1. Tahap Perencanaan

Pada tahap ini dilakukan persiapan tim yang terdiri dari tiga orang untuk studi lapangan atau tempat pelakasaan pengabdian, kemudian tim pengabdian melakukan wawancara dengan pihak mitra 
dalam hal ini adalah SMA Negeri 17 Palembang mengenai kebutuhan dari pihak sekolah. Analisis kebutuhan sangat diperlukan untuk mengetahui informasi, permasalahan dan kondisi yang ada sehingga tim dapat mengetahui perbedaan kondisi yang diharapkan dengan kondisi yang ada saat ini serta tim dapat mempersiapkan materi dan bahan pelatihan yang diperlukan untuk menunjang kegiatan berjalan dengan baik dan efektif. Langkah terakhir dalam tahapan perencanaan adalah menyelesaikan urusan surat perizinan kepada mitra yaitu SMA Negeri 17 Palembang.

2. Tahap Pelaksanaan

Tahap pelaksanaan dilakukan pada hari Kamis, tanggal 04 Maret 2021 yang bertempat di Laboratorium SMA Negeri 17 Palembang dan dibagi menjadi 2 sesi yaitu sesi pertama pukul 08.00 WIB sampai dengan pukul 10.00 WIB dan sesi kedua pukul 10.30 WIB sampai dengan pukul 12.30 WIB.

3. Tahap Evaluasi

Evaluasi pada pelatihan tersebut dilakukan selama proses berlangsung hingga akhir pelatihan yaitu melakukan diskusi dan tanya jawab dengan peserta pelatihan serta menghasilkan tampilan website baru yang lebih menarik dibandingkan dengan website sekolah yang lama.

\section{HASIL DAN PEMBAHASAN Instalasi WordPress}

Pada tahap awal dilakukan instalasi WordPress pada komputer guru dan pengelola website. Gambar 2 adalah tampilan halaman awal instalasi WordPress.

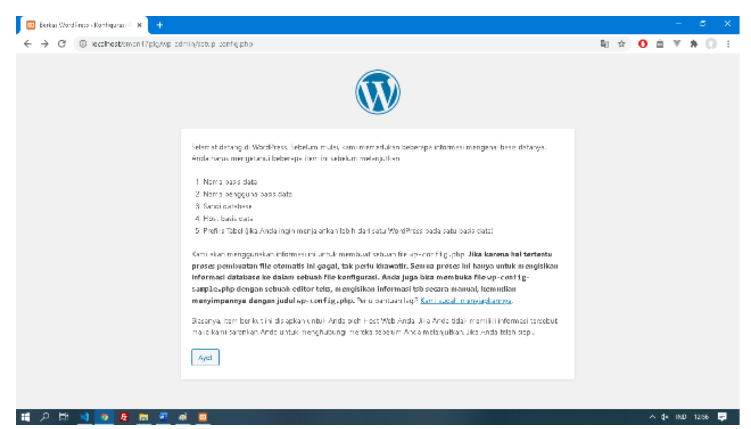

Gambar 2. Halaman awal instalasi WordPress

\section{Instalasi Plugin}

Setelah instalasi WordPress selesai, tahap berikutnya adalah instalasi plugin-plugin yang dibutuhkan seperti FG Joomla to WordPress, Elementor, WPBakery, dan All In One WP Security. Gambar 3 adalah tampilan halaman plugin pada Dashboard WordPress.

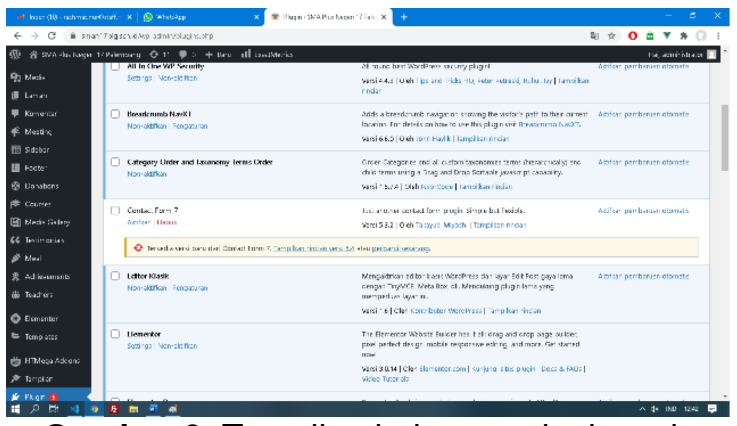

Gambar 3. Tampilan halaman plugin pada Dashboard WordPress

\section{Kustomisasi Halaman}

Halaman web yang menarik dapat membuat pengunjung kembali lagi ke halaman web tersebut. Untuk dapat membuat halaman web menarik dibutuhkan teknik kustomisasi halaman. Kustomisasi halaman pada WordPress dapat menggunakan plugin Elementor dan WPBakery. Gambar 4 adalah tampilan kustomisasi halaman.

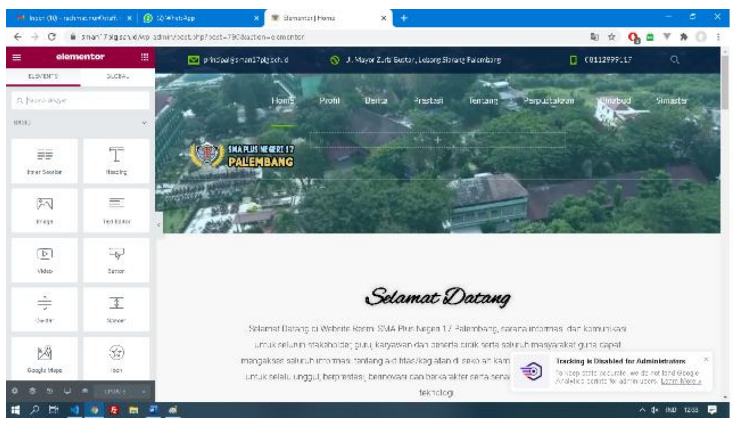

Gambar 4. Tampilan kustomisasi halaman

\section{Manajemen Pengguna}

Halaman manajemen pengguna hanya bisa diakses oleh administrator. Pada halaman ini, administrator dapat membuat akun pengguna dan mengatur hak akses pengguna. Gambar 5 adalah Tampilan halaman manajemen pengguna.

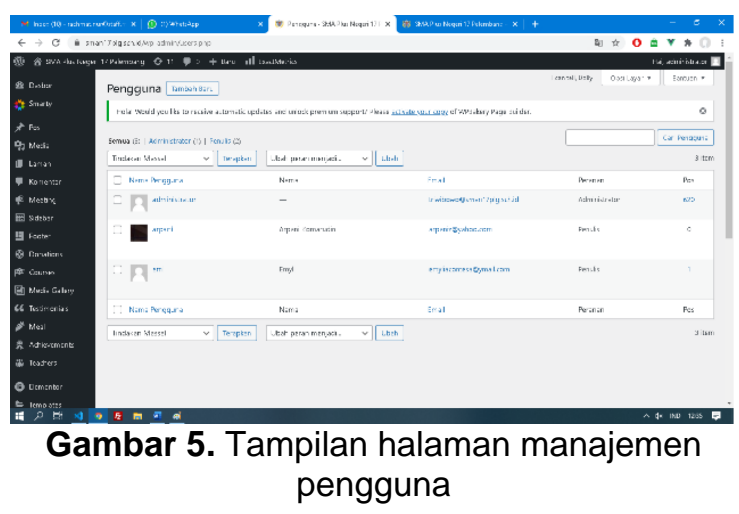

\section{Posting Informasi}

Pengelola dapat memposting informasi melalui halaman Pos pada Dashboard 
WordPress. Gambar 6 adalah tampilan halaman daftar postingan dan Gambar 7 adalah tampilan halaman input postingan.

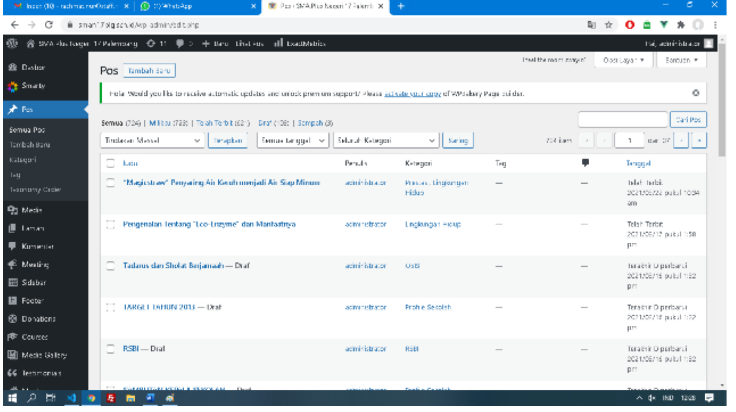

Gambar 6. Tampilan halaman daftar postingan

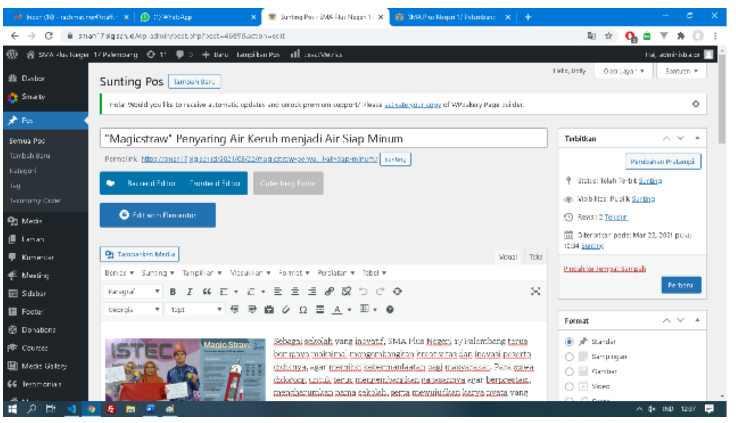

Gambar 7. Tampilan halaman input postingan

\section{Meningkatkan Keamanan Website}

Keamanan sebuat website merupakan hal yang sangat penting. Jika tingkat keamanan website rendah, kemungkinan untuk diretas sangat besar. Jika website berhasil diretas, peretas dapat posting informasi serta mengubah informasi yang ada pada website. Banyak plugin yang dapat digunakan untuk meningkatkan keamanan CMS WordPress, salah satunya adalah All In One WP Security \& Firewall. Menggunakan plugin ini, pengelola website dapat mengubah URL standar halaman login sehingga peretas akan kesulitan untuk mengakses halaman login. Gambar 8 adalah tampilan halaman dashboard All In One WP Security.

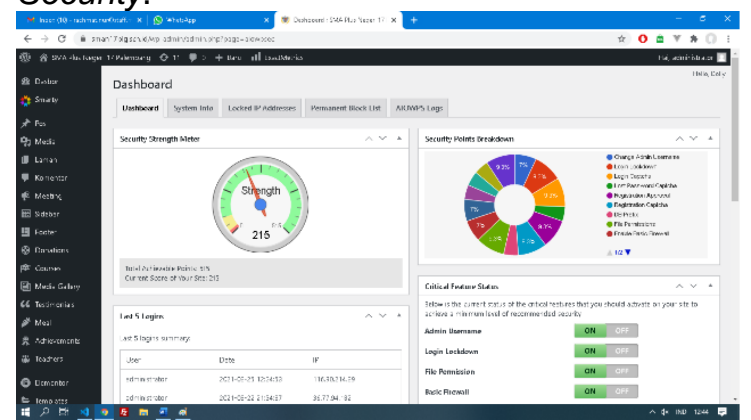

Gambar 8. Tampilan halaman All In One WP Security

\section{Pelaksanaan Kegiatan}

Pelaksanaan kegiatan diawali dengan diskusi terlebih dahulu dengan guru dan pengelola website SMA Negeri 17 Palembang membahas kebutuhan dari pihak sekolah. Gambar 9 adalah diskusi di ruang Samsung Smart Learning Class.

Dari hasil diskusi tersebut didapat bahwa SMA Negeri 17 Palembang sudah memiliki website utama di alamat https://sman17plg.sch.id// menggunakan Joomla. Joomla merupakan salah satu Content Management System (CMS) yang dapat digunakan untuk membuat sebuah website. Namun, jika diakses dari smartphone, tampilan website utama yang dimiliki SMA Negeri 17 Palembang belum responsif, sehingga pengunjung akan kesulitan mendapatkan informasi yang ada pada website tersebut. Kemudian dilihat dari tingkat kemampuan pengelola website yang tidak semuanya menguasai Joomla, sementara fitur-fitur yang disediakan Joomla sangat banyak, maka diusulkan pembuatan website baru SMA Negeri 17 Palembang menggunakan CMS WordPress dikarenakan fitur-fitur yang disediakan mudah dimengerti pengguna.

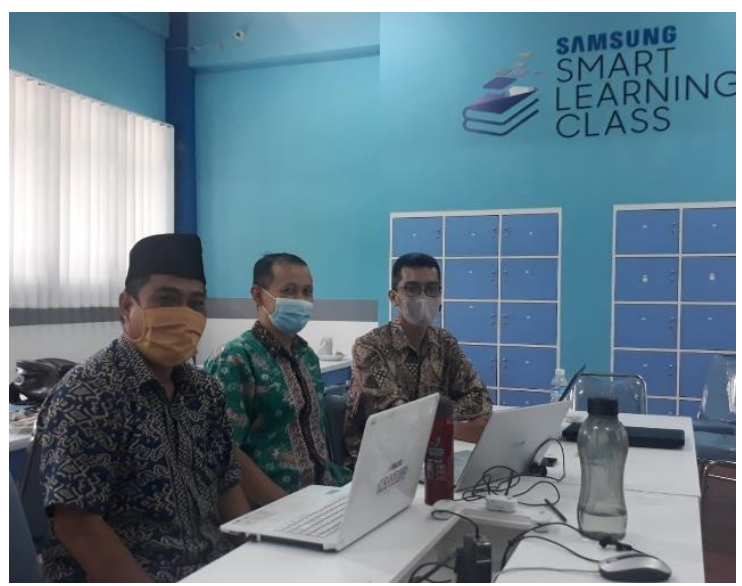

Gambar 9. Diskusi kebutuhan website sekolah

Adapun tahapan pembuatan website baru SMA Negeri 17 Palembang yaitu instalasi CMS WordPress pada komputer (localhost) meliputi instalasi XAMPP sebagai web server, instalasi CMS WordPress, instalasi plugin FG Joomla to WordPress digunakan untuk menyalin data berita dan halaman dari website lama ke website baru, instalasi plugin Elementor dan WPBakery untuk membuat halaman (page builder) web menggunakan teknik seret (drag) dan lepas (drop) serta instalasi plugin All In One WP Security \& Firewall untuk meningkatkan keamanan website yang menggunakan CMS WordPress. Peserta juga diajari bagaimana login ke halaman dashboard, posting berita, kustomisasi halaman sampai dengan publikasi website baru ke server hosting. Pelatihan pembuatan website baru SMA Negeri 17 Palembang dilaksanakan di Ruang 
Laboratorium Komputer SMA Negeri 17 Palembang dapat dilihat pada Gambar 10.

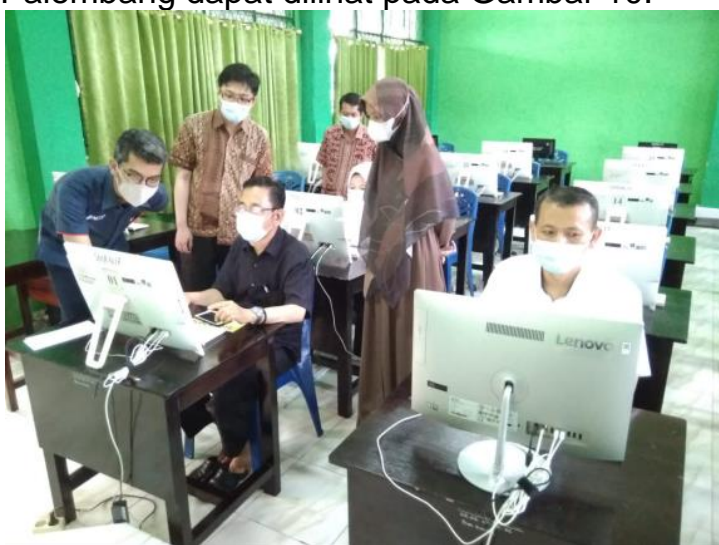

Gambar 10. Pelatihan Pembuatan Website

Setelah dilaksanakan pelatihan pembuatan website menggunakan CMS WordPress, berikut perbedaan tampilan website lama dan website baru SMA Negeri 17 Palembang dapat dilihat pada Gambar 11, 12, 13 dan 14.
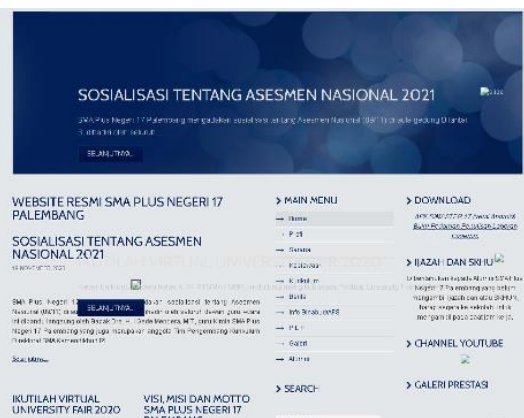

Gambar 11. Tampilan website lama di komputer

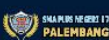

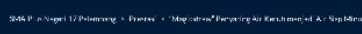

"Magicstraw" Penyaring Air Keruh menjadi Air Siap Minum

22 "Magicstraw" Penyaring Air Keruh menjad Air Siap Minum

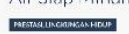
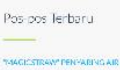

Gambar 12. Tampilan website baru di komputer

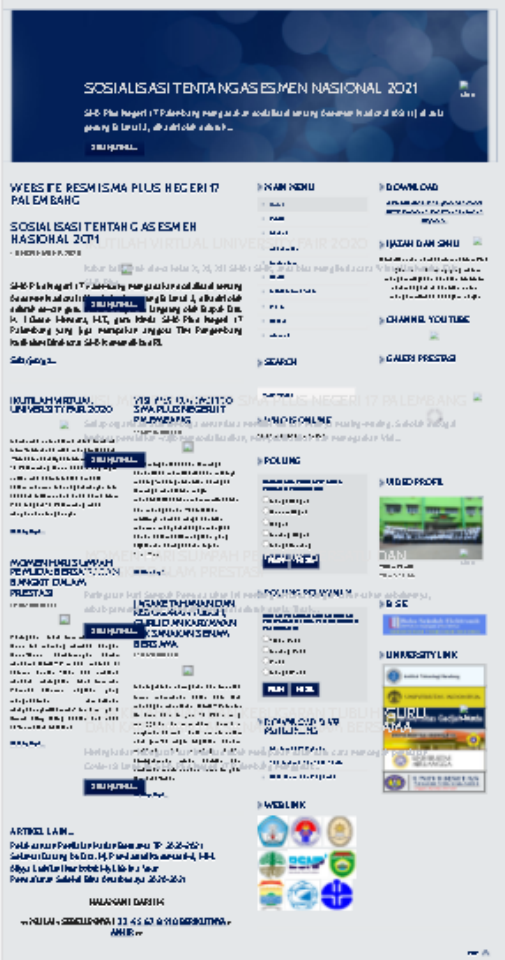

Gambar 13. Tampilan website lama di smartphone (belum responsif)
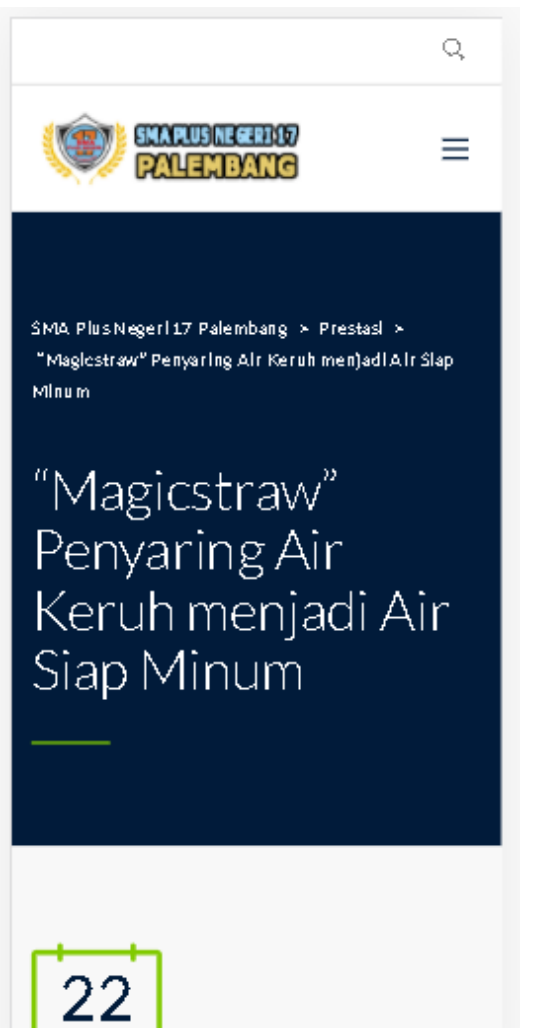

Maret

Gambar 14. Tampilan website baru di smartphone (responsif) 


\section{SIMPULAN DAN SARAN}

Dari kegiatan pengabdian kepada masyarakat yang telah dilaksanakan ini, terdapat kesimpulan, yaitu dengan adanya pelatihan mampu meningkatkan pengetahuan dan keterampilan guru TIK di SMA Negeri 17 Palembang dalam menghasilkan tampilan website sekolah yang lebih menarik dan interaktif. Serta membuka wawasan Guru TIK mengenai keuntungan dalam memanfaatkan website sekolah dalam mempermudah proses informasi mengenai profil dan berita - berita penting SMA Negeri 17 Palembang.

\section{DAFTAR RUJUKAN}

Hendriadi, A. A., \& Dedih. (2015). Analisis Web Menggunakan Google Analytic Untuk Menyajikan Laporan Data Situs dalam Proses Optimasi. Jurnal IImiah Solusi, 1(4), 20-26.

Pamungkas, R., Saifullah, S., Qoirrudin Raga Pratama, \& Cahyo, O. A. T. (2020). Pemanfaatan Website Desa Dalam Optimalisasi Informasi Publik kepada masyarakat di Desa Kiringan. DAYA MAS: Media Komunikasi Hasil Pengabdian Dan Pemberdayaan Masyarakat, 5(September), 32-38. http://dayamas.unmermadiun.ac.id/index. php/dayamas/article/view/43

Petreski, P., Ruhul, \& Ivy. (n.d.). All In One WP Security \& Firewall. Diunduh Tanggal 01 April 2021. https://WordPress.org/plugins/all-in-onewp-security-and-firewall/

Pratiwi, D., Santoso, G. B., Mardianto, I., Sediyono, A., \& Rochman, A. (2020). Pengelolaan Konten Web Menggunakan WordPress, Canva dan Photoshop untuk Guru-Guru Wilayah Jakarta Web Content Management Using WordPress, Canva and Photoshop for Teachers of the Jakarta Region. Jurnal IImiah Pengabdian Pada Masyarakat, 2(1), 11-15.

Siambaton, M. Z., \& Fakhriza, M. (2016). Aplikasi Content Management System (Cms) Pada Joomla Untuk Membuat Web Service. InfoTekJar (Jurnal Nasional Informatika Dan Teknologi Jaringan), 1(1), 11-13. https://doi.org/10.30743 /infotekjar.v1i1.32 